\title{
Does Dutch really have a Passive?
}

\author{
Louise Cornelis and Arie Verhagen
}

\section{Introduction}

Linguists usually characterize the structure and/or the function of 'the passive' as a counterpart of the so-called active voice; the terms in which such characterizations are cast are those of abstract patterns of roles. ${ }^{1}$ For example, it is common to find characterizations of the role of the grammatical subject in a passive clause as in some way the inverse of the role of the subject in the corresponding active clause; or of the role of the prepositional 'agent-phrase' as equivalent to the role of the subject in the active. Consequently, the function of constituents in a 'passive' is not characterized as determined by elements in the clause itself; in Dutch, such elements are the verbs worden ('become') or zijn ('be'), and the preposition door ('through'). Thus the common generalization over subjects of passives and objects of actives actually prevents another generalization, i.e. the one over all subjects of worden (or be in English, etc.); grammatical subjects of this verb are treated differently depending on the characterization of the clause as a 'passive' rather than a copula construction. As a corollary, the formal characteristics of 'passives' are seen as a consequence of their abstract nature, rather than as co-determinants of the meaning of the clause, as they are in non-passives.

A priori, it is not clear that one generalization is to be preferred over the other. In fact, considering formal elements of 'passives' the same as when occurring elsewhere definitely has some advantages: e.g., it allows for an explanation of certain differences between the two types of passives in (1) and (2):

(1) Tevens worden nog enkele deskundigen geraadpleegd.
At-the-same-time become yet some experts consulted
'At the same time some experts are being consulted'
(2) Tevens zijn nog enkele deskundigen geraadpleegd.
At-the-same-time are yet some experts consulted
'At the same time some experts have been consulted'

Sentence (1) expresses a process: the experts 'move into' the state indicated by the past participle (henceforth: "pp"), while sentence (2) expresses a (pure) state:

\footnotetext{
1 The research for this paper was made possible by a grant from the Netherlands Organization for Scientific Research NWO, Foundation for Language, Speech and Logic, for Louise Cornelis, grant nr. 300-173-027. Louise Cornelis would like to thank Eric Pederson.
} 
the experts 'are in' the state indicated by the pp. This difference can naturally be attributed to the difference between the lexical items worden ('become') and $z i j n$ ('be') that is also operative in other combinations. There are other functional differences between these two types of passives, related to this basic difference (we will return to an important one later), but here we just want to indicate that generalizing over worden and zijn in their 'passive' and non-passive uses seems to be an attractive option.

It were considerations like these that led Verhagen (1992), following Langacker $(1982,1988)$ to postulate 'analyzability' of passive constructions in Dutch: the specific linguistic elements actually constituting the construction are recognizably the same as when occurring in other combinations. Now analyzability as such is not the strongest possible claim. ${ }^{2}$ We might want to argue that elements of passive clauses are not only recognizable as elements with an independent meaning, but that the entire meaning of a passive construction is in fact completely determined by the combination of the meanings of its elements, in other words, that it is not just analyzable, but compositional (i.e. 'fully' analyzable). It is this possibility that has the consequence that Dutch would not have a passive construction: under full analyzability, all of what a 'passive' sentence means could be derived from knowledge of its elements and the manner of their combination. Of course, this would still imply that the language has means to express messages in which an agent is not prominent, but the passive construction would not exist in the (important) sense of a construction that requires independent grammatical characterization. In any case, postulating analyzability raises the question of its degree; $100 \%$ being the limiting possibility, the question of the existence of a passive in Dutch is unavoidable.

What we will do in the remainder of this paper is to explore this idea of full analyzability, in order to determine its viability. Our method will be to specify a number of consequences of the idea, and then determine whether these conscquences actually hold. On this basis, we will arguc that the degree of analyzability is in fact quite high, and that this approach provides an illuminating analysis of some otherwise mysterious phenomena. In the end, there is only one specific aspect of meaning that cannot be considered to be determined compositionally.

2 Compare an example at the word level: in a compound such as huisdeur 'front door' (lit.: 'house door'), the elements are each recognizably the same as the independent elements huis and deur. The strongest claim would be that the meaning of the compound is exhausted by the combination of its elements, which in this case is not true: the word has certain properties (it names the main entrance, not just any door of a house) that cannot be derived compositionally. 


\section{Combination of verb and past participles: a family of 'passives'?}

One consequence of the idea of full analyzability is that passive predicates are just combinations of the elements worden and zijn with a past participle. Consider the idea of replacing one of these 'auxiliaries' with some other verb, for example one that is semantically cognate to zijn. Full analyzability implies that the semantic difference between the resulting constructions should be fully attributable to the semantic difference between the verbs. Schematically:

$$
\text { wordentpp : zijn+pp : } X+p p=\text { worden }: z i j n: X
$$

Are there such elements that can take the place of $X$ in (3), and if so, what are the semantic consequences? Consider the following examples (taken from the so-called Eindhoven Corpus; version available at the Free University in Amsterdam).

(4) Donegal ligt aangevliid tegen het tot het Verenigde Koninkrijk behorende gedeelte van het Ierse eiland, het rocrige Ulster, $[\ldots]$

'Donegal lies nestled against the part of the Irish island belonging to the United Kingdom, turbulent Ulster, [...]'

(5) Vervolgens koos ik een entrecôte die als pain-pirotte op de kaart stond aangekondigd, en $[\ldots]$

'I then chose an entrecôte that stood announced on the menu as painpirotte, and $[\ldots]$ '

(6) Een hartverlamming krijgen, gaan beven, gaan zingen, trappelen, hoi roepen, de beest uithangen, schuimbekken, en dan de auto in, omringd door krachtige verplegers met zweepjes waarin rozen zaten vastgeknoont en leliën - klap klap - en hop naar het gesticht.

'Getting an heart attack, starting trembling, starting singing, stamping, calling whoopee, mess about, foam at the mouth, and then into the car, surrounded by strong nurses with little whips in which roses sat tied and lilies - crack crack - and up to the asylum.'

These are not purcly idiomatic (contrary to what the ANS (1984:528) seems to suggest) non-productive combinations. Within, of course, the limits of semantic compatibility all kinds of pp's may be combined with liggen ('to lie'), zitten ('to sit') and staun ('to stand'). Note, furthermore, that these verbs differ from the highly schematic zijn in that indicate specific 'ways of being', and that they differ from the processual worden in that they are all strictly stative. These specific semantic contributions are just as much present in cases like (4)-(6) as they are in other contexts. Thus, we do indeed have some differences here that may be ascribed completely to the words, and that need not be attributed to the constructions as units. 
The same argument can be made, we believe, with respect to the verb blijven ("to stay", 'to remain'), as meaning "continue to be". Cf. the following examples (also from the Eindhoven Corpus):

(7) In uitzonderlijke gevallen zou de regering de afkoeling moeten instellen, waarbij de regeling zo moet zijn, dat de stakingsvrijheid zoveel mogelijk gegarandeerd blijft.

'In exceptional cases the government would have to impose cooling-off, where the arrangement will have to be made in such a way that the freedom to strike remains guaranteed as much as possible.'

(8) Tijdens een reis komen er nu eenmaal dingen in een mons naar boven, die anders, thuis, bedekt blijven door de mantel van werk en gewoonte. 'During a trip things simply surface in a person which otherwise, back home, stav covered by the cloak of work and habit'.

Similarly, the use of krijgen in (9) also confirms the idea expressed in schema (3):

De balloncommandanten, een kleine twintig in getal, zullen vòor de opstijging een bepaald doel krijgen aangewezen, waarop zij zo precies mogelijk moeten landen.

'Before take-off, the balloon commanders, a little less than twenty, will get assigned a particular target, on which they have to land as precisely as possible.'

Note that the verb krijgen ('to get', 'to receive') in itself means 'be supplied with', 'be the beneficiary of' something, and that this exactly specifies the role of the subject, as well as the respects in which this construction differs from the 'passive' constructions. Thus given this meaning, the similarities and differences with the other $\mathrm{V}+\mathrm{pp}$-constructions, and especially the worden and zijn cases, again parallel the lexical differences exactly.

This way of looking at 'passives' is also interesting from a historical perspective. As shown by Van der Wal (1986, ch.2), the form that has become worden in modern Dutch, started out as indicating a transition into some state (not necessarily an instantaneous one), and alternated in Gothic with inchoative verbs. It is precisely this meaning that made it a suitable instrument for translating Greek synthetic passive forms. The claim of compositionality in the modern language implies that the difference between old and recent instances of 'passives' is not really very big, which both makes the development of the analytic 'passive' less of a mystery, and may explain why the older examples appear so familiar to speakers of 20 th century Dutch.

All in all, we seem to have strong confirmation for the correctness of the first prediction derived from the compositionality hypothesis, schematized in (3). 


\section{The role of the preposition}

Another characteristic formal feature of 'passives' is the use of a preposition, in Dutch door (lit. 'through'), to mark the agent. With respect to door, the consequence of the idea of full analyzability is that its complement should function in the same way as it does in other expressions. At first sight, this may seem an implausible claim to make, since this complement is usually described as "the agent phrase", and an agent is not an instrument or a conduit 'through' which a process unfolds. However, this approach in fact provides insight into some peculiar phenomena (see Cornelis 1994).

The main idea is that door indicates some intermediary factor in a process of change. When applied to more or less concrete concepts of place and time, the interpretation of the door-phrases is that of a kind of conduit; examples of this prototypical use of door are Hij ijsbeerde door de kamer ('He paced up and down through the room') and Hoe komen we door de slechte tijden? ('How are we going to get through the bad times?'). In more abstract processes of change, door indicates a more abstract type of intermediary factor with an instrument-like role:

Hij heeft door zijn optreden alles bedorven.

'Through his behavior he ruined everything.'

Now we claim that passive cases like (11), and especially causative cases like (12), are immediate extensions of this type of usage:

(11) Door zijn optreden werd alles bedorven. 'Through his behavior everything was ruined.'

Hij heeft zijn huis laten bouwen door een aannemer. $\mathrm{He}$ has his house let build through a contractor 'He's had his house built by a contractor'

The causee in (12) (i.e. the contractor) is an intermediary factor, an instrument in the entire causal event of which $H e$ is the actual agent, the ultimate intentional energy source (cf. Kemmer \& Verhagen (1994) for a general analysis of this type of event structure). The special feature of a passive clause is that it also evokes a causal event, but does not (have to) mention another causal factor besides the one in the door-phrase (which may of course also be absent itself, like any other adjunct). It remains true, however, that this phrase does not indicate a standard, prototypical kind of agent, but one with somehow 'reduced' causal powers. In a case like (11), this is obvious from the fact that it is the 'possessor' of the behavior who is the ultimate agent (note that it can be read as a paraphrase of (10)). But interestingly enough, it is also true in less obvious cases; consider the following examples (from the Eindhoven Corpus again): 
(13) Hij wees daarbij op het landsbestuur waar de besluitvorming door de talloze commissies en raden vertraagd wordt.

'In that respect he mentioned the national administration where decision making is delayed by (lit. through) the countless committees and councils.'

(14) Het resultaat was dat het telefoonverkeer ontregeld werd door alle verontruste ouders van hennep-gebruikende kinderen die de watrheid aan den lijve kenden.

'The result was that telephone communications were disrupted by (lit:: through) all worried parents of cannabis-using children who knew the truth from personal experience.'

When we construct active counterparts of such cases (...de talloze commissies vertragen de besluitvorming, "...the countless committees delay decision making'; ...alle verontruste ouders van hennep-gebruikende kinderen ontregelden het telefoonverkeer, '...all the worried parents of cannabis-using children disrupted telephone communications'), it is apparent that it is only in the active clauses that the committees perform the delaying deliberately and that the parents consciously obstruct telephone traffic. In the passive cases, the interpretation is that the situations of there being countless committees and worried parents, respectively, simply cause things like delaying of decision making and disruption of telephone communications to happen. Here we clearly have reduced agentivity. The 'agents' are actually not prototypical ones who willfully bring about intended results; rather, their properties are causally related to the result in a way that resembles an intermediary factor like an instrument, which justifies the use of door. This insight may actually explain a curious fact of linguistic usage: Sentences of the type Bill was hit by Mary, figuring prominently in linguistics discussions, are actually quite uncommon. In written Dutch, for example, $2 / 3$ of passive 'agents' are inanimate as opposed to only $1 / 3$ of active agents (Cornelis 1995:132), which is all the more telling when combined with the fact that $80 \%$ or more of passives is agentless. There are indications that even the few cases of this type exhibit some effect of distancing from a 'prototypical' agent, if only in terms of identification and empathy (but we leave the elaboration of this point for future research).

So it is with respect both to the specific verbs used in 'passives', and to the preposition marking the 'agent', that the expectations derived from the hypothesis of compositionality actually come true. The possibility that Dutch does not have a passive, in the sense described earlier, seems to become more and more serious.

However, before we draw the conclusion that there is no passive in Dutch, but only a number of constructions with a stative auxiliary and a past participle, we will take another look at the construction with worden, the most likely candidatc to be called 'passive'. This construction has one characteristic that should not be overlooked. In the next section, we will present that characteristic and its consequenses for the compositionality hypothesis. 


\section{The causer}

Consider the following sentences:

$$
\begin{aligned}
& \text { Hij raakte opgesloten } \\
& \mathrm{He} \text { got locked-in } \\
& \mathrm{Hij} \text { zit opgesloten } \\
& \mathrm{He} \text { sits locked-in } \\
& \mathrm{Hij} \text { werd opgesloten } \\
& \mathrm{He} \text { became locked-in }
\end{aligned}
$$

These three sentences differ markedly as to who is responsible for the locking in of he. Raken, (15), seems to suggest that the event happened through 'his' own fault or by accident. In (16), the responsibility is vague; the question who is responsible cannot be answered. In (17), however, there has to be a responsible person or instance other than the he himself. This external causal factor is an important difference between worden+pp constructions and all the other $\mathrm{V}+\mathrm{pp}$ constructions in general. It is this 'causer' who, in most of the literature on the passive, is called the agent or the logical subject. It is also the participant who can be made explicit by means of the door-phrase (of which we described some characteristics in section 3 ).

4.1. Consequences for the compositionality hypothesis. The worden $+\mathrm{pp}$ construction always implies that there is an external instance or person, somehow involved in causing the process that leads the subject of the sentence to the end state expressed in the pp. Consider the following sentences (cf. Verhagen 1992:323):
Haar lijfwacht was uitgerust met automatische wapens
'Her bodyguard was equipped with automatic weapons'
Haar lijfwacht werd uitgerust met automatische wapens
'Her bodyguard was being (lit. became) equipped with automatic weapons'

(18), with zijn, refers to a given fact, a state, and it does not make much difference who equipped the bodyguard. With worden in (19), however, it cannot be the case that the woman that haar ('her') refers to did the equipping herself. Yet there

\footnotetext{
${ }^{3}$ The English get + pp construction is an approximation of the Dutch one with raken. For the intended reading is the inchoative one with get, not the passive one (cf. Van Dale E-N:592).
} 
has to be someone who did it. Again, there is an external (implicit) causer in the worden-construction, which is not necessarily there with zijn.

The presence of the causer is problematic for the compositionality hypothesis, because it cannot be attributed to (one of) the parts of the worden+pp construction. There is not always an (implicit) causer in sentences with worden, because in sentences with worden without $\mathrm{pp}$, as in hij werd ziek ('he became ill'), there is no causer. There is no external causal factor involved in him becoming ill, or, at least that presence is not 'enforced' by the linguistic expression itself. There is not always a causer present in pp's either, because, as we have seen, Dutch has plenty of constructions with a pp in which the responsibility is vague or not considered; (15) and (16) are examples of those constructions, and so are the other combinations discussed in section 2 (with liggen, staan etc.).

The presence of the causer in wordentpp constructions cannot be explained on the basis of the parts of the construction alone. For full analyzability, the presence of the causer is a serious problem; the worden+pp construction is not compositional. Does this mean that Dutch has a passive after all? If the meaning of the worden+pp-construction cannot be derived from the meaning of its parts, it means that the construction has a meaning of its own, and it is because of this extra meaning that the construction could be called 'passive'. However, such a conclusion may still be premature, because the presence of the actor raises the question how this aspect of the worden+pp-construction could have come about, since it has not always been there, as we have seen in section 2. In order to answer this question, we will have to look at the history of the pp-constructions again.

4.2. Diachronic aspects of the causer. As we saw at the end of section 2, the Middle Dutch worden + pp constructions had an inchoative meaning. Middle Dutch Hi wart ghevallen ('He became fallen'), for example, meant 'he came/happened to fall', or simply 'he fell' (Van der Wal 1986:126). In Middle Dutch, therefore, the passive did not exist; worden+pp constructions were just like other pp constructions in not necessarily indicating that an external causer was involved. If the passive did not exist, and if we want to claim that it exists now, the question arises how the passive developed, or, rather, how the causer came into play. We would like to suggest the following (tentative) answer to this question.

Middle Dutch worden + pp indicated the process of transition into another state. In the case of transitive verbs, this process implies that there is someone or something causing the transition. Our suggestion is that the presence of the causer developed from this implication in worden+pp's with transitive verbs. The causer could have started as a pragmatic inference, and, as happens more often in grammaticalization processes (see, for example, Traugott and König 1991), this pragmatic inference could have become stronger, until the interpretation with a causer had overtaken the old one without: the 'passive' had come into being. This 
meaning could have ousted the old one; what started off as a feature of one particular subcategory of worden+pp (i.e. with transitive verbs) became a feature of the whole class and eventually changed the meaning of the other subcategories as well.

Four facts from the history of the $V+p p$ constructions seem to indicate that something like this process may indeed have taken place:

1. Since the Middle Ages, 'passives' with verbs like vallen ('to fall'), as in "Hij werd gevallen ('He has been fallen', lit. 'became fallen') have become impossible. With these verbs, it is impossible to imagine how an external causer could cause the falling; falling happens through your own clumsyness, or as a result of stumbling. The fact that these sentences have become ungrammatical indicates that the inference from the transitive subcategory has been generalized to the intransitive subcategory.

2. Other non-transitive verbs have kept the possibility to form combinations with worden: er werd gedanst ('There became danced, there was dancing') is still possible, because in these 'impersonal passives', the presence of a causer is thinkable: dancing is something people do out of their own free will; the dancers can be seen as somehow causing their own actions. Indeed it is possible to add a door-phrase (door de feestgangers, 'by the party-goers'). Only some intransitive verbs have kept the possibility to combine with worden, because only if a causer was possible, these verbs could form impersonal (or 'pseudo') passives.

3. In (15) we saw that raken also forms a passive-like construction. Just like worden, it has a processual meaning, but without a compulsory causer. Although there are some differences (raken often suggests some sort of good or bad luck or coincidence), raken now has roughly the same meaning as worden had in Middle Dutch $(M N W$ X, 1003/1004). Raken could not be used this way in Middle Dutch. An example of the usage which is most like it is (20):

$$
\begin{array}{lllll}
\text { Avont } & \text { waest } & \text { eer } & \text { si thuus raecte } \\
\text { Evening } & \text { it-was } & \text { before } & \text { she home got }
\end{array}
$$

In this sentence, she was lucky to eventually reach home. Raken with a pp as a combination, however, is excluded for Middle Dutch by the $M N W$; raken has gained this usage since the Middle Ages. The oldest example in the dictionaries is (21), from 1708 (WNT XII,III 206).

(21) Gaa liever vroeg naar kooi; Of 't neerstuk raakt gekreukt. Go better early to bed; or the undervest gets wrinkled

1708 is after the Middle Dutch period, so also after the period in which the 'passive' could have become dominant over purely inchoative worden-constructions. This means that it could have been the case that raken took on worden's old 
meaning of a process leading to a state without external causer. Raken acquiring a new meaning seems to indicate instability and shifts in the V+pp constructions. Another one of these shifts could have been the rise of the passive.

4. Sometimes, speakers produce constructions with both zijn and worden, as in Het brood is gebakken geworden (lit. 'The bread is become baked'). Interestingly, this construction is younger than the simple zijn-construction (Van der Wal 1986:197). This, and the fact that this construction also necessarily evokes a causer, can be explained under our hypothesis: after the Middle Ages, worden+pp is no longer simply the inchoative of $z i j n+\mathrm{pp}$, and then it becomes possible to combine both schemas in one utterance in order to explicitly indicate that a state both exists and has been produced by an external causer.

Since the Middle Ages, the presence of the causer has become a necessary inference of all wordentpp-constructions. It is because of this presence that we can no longer claim that the Dutch 'passive' is compositional, i.e. fully analyzable: the meaning of the wordentpp-constructions is not completely determined by the combination of the meanings of its elements.

\section{Conclusion}

Does Dutch have a passive construction, or doesn't it? In view of the previous section, it is obvious that the answer is "Yes": worden+pp is the Dutch passive.

But we cannot confine ourselves to this answer as it stands, for it does not explain the fact that worden $+\mathrm{pp}$ bears similarities to raken+pp, zijn+pp, liggen+pp, in other words, that worden is but one of the stative auxiliaries to be combined with a pp. Also, it does not do justice to the fact that the meanings of the parts of the construction (worden, pp, door) each contribute to its overall meaning: The construction is not compositional, but it is at least partially analyzable. It is because of these characteristics (the relationships with other constructions and the meanings of the parts) that the Dutch passive is a considerably different passive than, for example, a synthetic one, or one which is formed with reflexives.

Taken in isolation, these considerations suggest that the answer to our question might have been "No". That would amount to saying, briefly: Dutch does not have a passive, it only has one specific verb out of a group of related stative verbs which, when combined with a pp, enables a presentation of a causal event without the causer central. This construction, with worden, looks like other, related constructions that have passive-like characteristics, such as with zijn and raken, but it would go too far to call all these constructions 'passive'. Moreover, this position entails that the worden-construction is not a counterpart of 'active' but an independent construction, with properties determined by its constituting parts. 
But attractive as it may be, this answer is unsatisfactory because it ignores the fact that the worden $\mathrm{pp}$ construction is more than the sum of its parts. The construction is not compositional, and its non-compositional element (the causer) is also the main reason why it is really different from the related constructions. ${ }^{4}$ The fact that the worden-construction implies a causer, but does not centralize it, is the crucial characteristic of the passive (cf. Kirsner 1976, Verhagen 1992, Cornelis 1995).

So what we have to do is to 'embed' the yes-answer in a comprehensive description making the relationships with other constructions explicit. We would like to present this as in the network in figure 1 (cf. Langacker 1988). ${ }^{5}$ This network can be explicated as follows: Dutch has a category of which the most abstract and global label is 'stative verb + past participle'. ${ }^{6}$ Of that abstract schema, we have seen two still abstract instantiations: 'process verb + pp' and 'zijn-like stative verb + pp'. Further instantiations of the first subschema are raken and worden $+\mathrm{pp}$, and of the second $z i j n$ and blijven $+\mathrm{pp}$. This second subschema has an intermediary schema of 'a certain way of being', with instantiations with liggen, zitten and staan. All these schemas can be used by language users to be filled in with concrete verbs, as we have seen. Each subcategory has relations with the others in the category, but also with related networks outside this one. Liggen+pp, for example, is connected to the network for liggen, in which other usages of that verb are represented, etc. ${ }^{7}$

So Dutch has a network of passive-like stative auxiliary + past participle constructions, one of which is different from the others because of the compulsory presence of a causer, and therefore has a degree of semantic salience that the others do not have. The construction with worden is an integral part of the network, thus similar to other parts and analyzable; on the other hand it is unique in that it has the characteristics of what is traditionally seen as passive.

${ }^{4}$ Our claim is that not even zlyn resembles worden in this respect Although zlyn allows the possibility of an actor (and is therefore often called the perfective aspect of the passive), the presence of the actor is not or not always compulsory It could be claimed that there is a zlnn-passive in Dutch, but then there is a blyven-passive too, because example (8) shows that blyven allows a door-phrase, too And if there is a blyven-passive, then there is a zitten-passive, too, and a raken-passive, etc

s For background and details of this dea of networks (such as bold lines indicating salience of a category, etc ), see Langacker 1988

6 This category itself is part of an even more abstract category of 'verb + past participle', but that is an aspect we have left out of our argument

7 A network representation makes clear why some differences in traditional grammar present such problems for analyses, both in lingustics and at school The distinction between a passive perfect and a nominal predicate, for example (hly is teleurgesteld, 'he is dissapponted'), bas puzzled generations of school children Distnetions like these have been made by analysts with the best intentions, but they may not always correspond to the categories of a language, and it is not surprising that school children only learn to make them by means of 'tricks' 


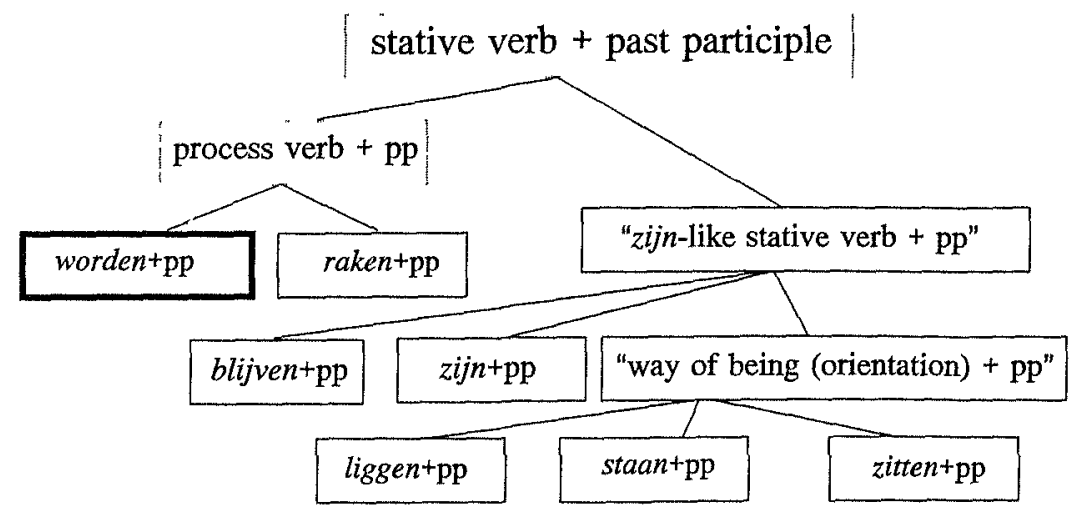

Figure 1

\section{References}

ANS (1984) Algemene Nederlandse Spraakkunst. G. Geerts, W. Haeseryn, J. de Rooij, M.C. van den Toorn, eds., Wolters-Noordhoff, Groningen.

Cornelis, Louise H. (1994) 'Passing through Passives', in R. Boogaart \& J. Noordegraaf, eds., Nauwe betrekkingen. Voor Theo Janssen bij zijn vijftigste verjaardag. Amsterdam/Münster: Stichting Neerlandistiek VU/Nodus Publikationen, 22-30.

Cornelis, Louise H. (1995) 'Problemen met het Passief', De Nieuwe Taalgids 88, 124-136.

Kemmer, Suzanne \& Arie Verhagen (1994) 'The Grammar of Causatives and the Conceptual Structure of Events', Cognitive Linguistics 5, 115-156.

Kirsner, R.S. (1976) 'On the Subjectless "Pseudo-Passive" in Standard Dutch and the Semantics of Background Agents', in Charles N. Li, ed., Subject and Topic, Academic Press, New York, 385-415.

Langacker, Ronald W. (1982) 'Space Grammar, Analysability, and the English Passive', in Language $58,22-80$.

Langacker, Ronald W. (1988) 'A Usage-Based Model', in Brygida Rudzka-Ostyn ,ed., Topics in Cognitive Linguistics, John Benjamins, Amsterdam/Philadelphia, 127-161.

MNW (1969-1977) Middelnederlandsch Woordenboek, by E. Verwijs and J. Verdam, voltooid door F.A. Stoett, Nijhoff, 's-Gravenhage.

Traugott, Elizabeth Closs and Ekkehard König (1991) 'The Semantics-Pragmatics of Grammaticalization Revisited', in Elizabeth Traugott and Bernd Heine, eds., Approaches to Grammaticalization, vol. $1,189-218$.

Van Dale E-N $\left(1989^{2}\right)$ Van Dale Groot Woordenboek Engels-Nederlands, by W. Martin and G.A.J. Tops. Van Dale Lexicografie, Utrecht/Antwerp.

Verhagen, Arie (1992) 'Praxis of Linguistics: Passives in Dutch', Cognitive Linguistics 3, 301-342. van der Wal, Marijke J. (1986) Passiefproblemen in Oudere Taalfasen, Diss. University of Leiden. WNT (1916) Woordenboek der Nederlandsche Taal, Nijhoff en Sijthoff, 's-Gravenhage en Leiden. 